\title{
Spirituality of liberation: A conversation with African religiosity
}

\begin{abstract}
Author:
Vuyani S. Vellem ${ }^{1}$

Affiliation:

${ }^{1}$ Department of Dogmatics and Christian Ethics, Faculty of Theology, University of

Pretoria, South Africa

Correspondence to: Vuyani Vellem

Email:

vuyani.vellem@up.ac.za

Postal address:

Private Bag X20, Hatfield

0028, Pretoria, South Africa

Dates:

Received: 03 June 2014

Accepted: 05 July 2014

Published: 20 Nov. 2014

How to cite this article:

Vellem, V. S., 2014,

'Spirituality of liberation: A

conversation with African

religiosity', HTS Teologiese

Studies/Theological Studies

70(1), Art. \#2752, 7 pages.

http://dx.doi.org/10.4102/

hts.v70i1.2752

\section{Copyright:}

(C) 2014. The Authors.

Licensee: AOSIS

OpenJournals. This work

is licensed under the

Creative Commons

Attribution License.
\end{abstract}

Read online:

Scan this $Q R$ code with your smart phone or mobile device to read online.
The arrival of a salvationist, authoritative religiosity through Western Christianity in South Africa, in the company of a capitalist modernity, did not only dismantle and subvert the African indigenous dispensation of religiosity. It also sought to destroy it completely and arguably continues to do so in subtle forms in the 21st century, by attacking the imagination and consciousness of black Africans. This article argues that African religiosity as expressed in African Initiated Churches (AICs) is the site of the spirituality of liberation. Employing the notion of mokhukhu - a shack - the article places the sanity of black Africans, the spirituality of liberation, black African agency and consciousness within the narrative of African religiosity. It concludes by offering African religiosity as a resource for an alternative civilisation and an important agenda in the current debates of the World Communion of Reformed Churches.

\section{Introduction}

This article originated from an address presented by me at the University of Stellenbosch in 2013, at a conference that was held under the auspices of the South African Missiological Society (SAMS). The original title of the address was 'Christian spiritualities of liberation and human dignity: A conversation with African religiosity (African Traditional Religions).' I have reworked that paper and changed the title to its current form mainly to give it a focus on liberation spirituality and its locus in African religiosity. The main argument of this article is that African religiosity is the site of liberation spirituality. For this reason, African religiosity does not require inclusion in Western frameworks but equal recognition as a value system amongst others. The article first presents an overview of liberation spirituality from the point of view of a struggle against a salvationist, authoritative religiosity that was transplanted to South African soil. It highlights the resources of spirituality of African religiosity expressed through the African Independent Churches as a response to this salvationist, violent and subjugating form of Western religiosity. As a site of the spirituality of liberation it is argued that African religiosity offers resources for cultural liberation, African history, black African agency and moral consciousness. African religiosity, the article further argues, is a resource for an alternative civilisation in the context of empire ${ }^{1}$ and concludes with a brief reflection on current debates in the World Communion of Reformed Churches.

\section{An overview of spirituality in African religiosity}

It is now common cause in theological circles that before the arrival of Western Christianity on the African continent, there was a free dispensation of moral and ethical thought that shaped the lives of the black African people. Black African encounters with Christianity essentially meant an encounter with modernity. The modernist ethos not only disrupted the norms and values of the life of black Africans, but also their spiritual dispensation. As a black Reformed Christian in South Africa, it would be logical to include Reformed faith as part of this modernist ethos, at least in as far as black Africans have experienced its transplantation as part of the missionary enterprise and later as a distorted theological basis for apartheid in South Africa. It should be conceded that Western Christianity, including Reformed faith, became a form of religion that became authoritative and argued broadly for a salvation based on 'true' belief.

Western Christianity became an expansionist religion concomitant with modernity, but also with terror as experienced by black Africans in South Africa. In this manner, Western Christianity became part of the historical disruption of the moral and ethical dispensation of life amongst black Africans. Some further explanation is probably necessary, but more importantly, this historical perspective requires to be punctuated at this very point of our conversation as it forms the basis of this overview. Ngugi wa Thiong'o (2009) conveys this as follows:

1.I use the notion of empire as shorthand for my social analysis, taking my cue from the numerous works that have been published since the adoption of the Accra Confession in 2004. Cf. Koshny (2006), the entire volume is dedicated to the notion of empire. Also cf. Vellem (2012). 
When Vasco da Gama set foot in Cape Town in 1498, it was part of the general period of what has come to be known as the European renaissance, the founding moment of capitalist modernity and Western bourgeois ascendancy in the world. It was also the beginning of the wanton destruction of many city civilizations along the coast of Africa, Eastern Africa in particular. (p. 52)

Following the sentiments above, we identify this as an important starting point of our overview of the spirituality of African religiosity, the beginning of the destruction of African civilisations to synchronise with the ascendancy of capitalist modernity and the expansion of Western Christianity. Within this history, we should remember that the Reformed tradition, upon its emergence, posed the question of salvation in a context that provided a number of answers to this very question: the context of Europe. It was a deep question of salvation in the sense that it asked how one person could live with people who are different and appeal to different sources of truth. The Reformed faith proposed its own authoritative doctrine of salvation. It was a form of a salvationist religion. Essentially, in other words, the arrival of the Reformed faith in the history of the West brought about rivalry around the understanding of authoritative marks or criteria of salvation. Students of the Reformation should be familiar with the violence, upheaval and revolt associated with this tradition. This rivalry of 'authoritativeness' and 'truthfulness' around salvation is a contest that in the West resulted in the liberal tradition and various forms of toleration in the ultimate recognition of a plurality of truth references, ostensibly as they existed in the West.

The success of the liberal tradition is probably true only in the West because the expansion of Western Christianity ${ }^{2}$ became historically intolerant, authoritative and violent in other parts of the world, especially in Africa and more particularly in South Africa. The propulsion of an authoritative salvationist form of religiosity characterised with violence and intolerance constitutes the major point of contention in this overview. It is simply unavoidable. To clarify how black Africans responded to this form of religiosity from the West the concepts African religiosity and spirituality are used synonymously. Anderson (2000:17) perceives the two terms 'spirituality' and 'religiosity' to be more or less the same.

In the light of the foregoing background, it is important first to argue that African religiosity maintained the sanity of the African soul within the underbelly of modernity. The narrative of the AICs is an expression of this spirituality of sanity in the context of a political, economic, spatial and cultural domination of a salvationist religion of the West ironically experienced as terror by black Africans. Nontetha Nkwenkwe is a quintessential epitome of the lived space of insanity by black Africans under colonial and apartheid rule

2.John de Gruchy in his work, Liberating reformed theology, argues that the problem in South Africa was both Calvinism and Catholicism. One of the most important point he makes is the parallel he draws between the Reformed tradition or Calvinism in he makes is the parallel he draws between the Reformed tradition or Calvinism in the South and Roman Catholicism in Latin America (1991:10-13). More recently, Chung, Duchrow and Nessan in their 2011 work, Liberating Lutheran theology, particularly the section on Latin American liberation theology by Nessan, argue that the Roman Catholic Church is clearly not innocent in the history of genocide in Latin America. This note therefore seeks to clarify that it is not only the Reformed faith that became tainted outside Europe, particularly in the era of the Europeanisation of the world, but other traditions like Roman Catholicism too. with Western Christianity as an accomplice. She remains one of the remarkable examples of a religious leader, and in this case a woman, a seer and a prophetess who was incarcerated by the colonial authorities for resisting to submit to the psychic-cultural dominance of the West. She was not only incarcerated; in fact, she was committed to Fort Beaufort mental hospital in 1924 and later to Weskoppies mental hospital in Pretoria.

One of the things Nontetha promoted amongst black Africans was the unity of Amaqaba (the red-blanketed ones) and Amagqhoboka (the educated ones). The division of the black African communities between those who accepted Christianity and those who did not was also expressed through the division of the land between 'mission station' and 'mission field.' Because of her commitment to unity, Nontetha was seen as a problem because the colonial regime benefited from the division of black Africans and indeed actually fuelled these feuds. She was declared mentally ill, insane! This because she led her people with the values and norms of salvation rooted in her own culture and African religious views. By way of illustration, in November 2012, in a Roundtable of the Centre for Public Theology in Pretoria, Puleng Segalo, a psychologist, was not hesitant to predict that according to the Diagnostic Statistical Manual (DSM), anyone with diphaephae ${ }^{3}$ would be found to present symptoms of disorder - mental disorder surely.

Whilst the DSM is a tool employed by psychologists to diagnose mental disorders scientifically, this illustration shows that it might be inadequate once it crosses frontiers into systems of knowledge that are foreign to Western thought. In the history of the encounter between the West and Africa, Nontetha represents an embodied text of the diagnosis of black African spirituality as a form of mental disorder by the powerful, 'superior' and arrogant West.

A commentary from Max Stackhouse might help us grasp this notion of diphaephae better. He says that traditional social sciences have limitations as they often fail to fully grasp that we live in a world of vital, intelligible, spiritual forces that were created to be obedient to divine laws ...' (Stackhouse 2004:185). Failure to grasp the existence of such powers arises from the fact that 'they do not believe that we live in a world of vital, intelligible, spiritual forces that were created to be obedient to divine laws as servants of divine purposes' (Stackhouse 2004:185). Unfortunately, the realm of the spirits, as part of the view through which the imagery of the cosmos is formulated by black Africans, has become a constant casualty and victim of the most powerful in the world.

Arguably, the notion of mokhukhu could be helpful to capture this deficient grasp of the reality of the spiritual forces that are part of our created order (see Vellem 2013). A mokhukhu

3.Diphaephae is a Sesotho word that is used to describe an entranced person, a person who is on a 'high' spiritually. In isiXhosa, the phrase that is used to describe this moment is: uphethwe ngu moya. It expresses a similar sentiment although it specifically brings the idea of the spirit taking a person over. This phenomenon is not specifically brings the idea of the spirit taking a person over. This phenomenon is not
easy to describe, one has to witness it when it happens. This state, often rife among traditional healers, is about a 'flight' into another realm to fight for life. 
is a shack in which people live, mostly in peri-urban South Africa. It is a structure associated with the ghetto. It is a symbol of struggle for life in squalor and sordid conditions. It connotes psychosis in and amongst those who are living in the underside of history and it is fast becoming a habitat for urban black South Africans. Indeed it is part of the history of evictions, a tale of displacement and dumping of black Africans at will for the pleasure of others in our land. Yet, it is also a symbol of the spirituality for a black African person. One of the biggest churches in South Africa, the Zion Christian Church (ZCC) is known for this. The same word mokhukhu is used to capture the choreography and liturgical dance of the members of this church. When they dance, they do mokhukhu! This phenomenon, mokhukhu, in Nigel Gibson's (2011) description of life in the squalid informal settlement is tantamount to 'living death.' The point cannot be over-elaborated. When one looks at the various dimensions of life symbolised by mokhukhu, one cannot but conclude that African religiosity provided sanity to black Africans in living death.

African religiosity is the site of spirituality of liberation. It offers the methodological sources for the search of this spirituality of liberation in our South African context. By the close of the 20th century, after the distinct phases of African theology's reflection on African religiosity, the AICs had been linked to praxis and thus the tradition of liberation and resistance. Maluleke (1997) argued:

The basic proposal of many AIC 'theologians' is that the praxis of these churches must now be regarded not only as the best illustration of African Christianity, but also as 'enacted', 'oral', or 'narrative' African theology-a type of theology which is no less valid than African theologies, they would add. (p. 17)

The point intended here is that the sight and witness of mokhukhu, is equally the sight and witness of an enacted, oral narrative of the sources for the spirituality of liberation. Indeed the sight and witness of this praxis, as Maluleke (1997:18) further argued, must be viewed as 'a "problem", "reflection", or "failure" of "missionary work", ipso facto, a subversive statement and enactment of the narrative of life against a dominating salvationist paradigm of the religion of Western Christianity. We need to remember that the religiosity of Western Christianity equals cultural subjugation of the black Africans who were colonised. Black theology of liberation and its relationship with Black Consciousness should be understood in this way, particularly the psychosocial dimension of this school. Ngugi wa Thiong'o (2009) says cultural domination is even more dangerous than political and economic subjugation:

[B]ecause it is more subtle and its effects long-lasting. Moreover, it can make a person who has lost his land, who feels the pangs of hunger, who carries flagellated flesh, look at those experiences differently. (p. 57)

As an expression of indigenous culture and spirituality, mokhukhu is a spirit that refuses to be killed by the existential challenges and failures resulting from the subjugating and death dealing form of the religiosity of Western Christianity. Lamin Sanneh (2001) aptly says:
Africans are not like children, fixed for life from the first white impressions. Thus you do not have to deny the presence of Europeans in Africa to believe that African history abides by its internal logic, that African agency is authentic, that African themes are original, and that an African outlook on life shapes people's historical and moral consciousness. (p. 11)

Mokhukhu is used here to aggregate the symbolic meaning of AICs and African spirituality. Mokhukhu enacts the internal logic of African history, the agency of black Africans, their originality and moral consciousness.

One cannot forget that missionaries purposed to dismantle the indigenous cultural dispensation of black Africans. Furthermore, subverting the black African genius was one of their objectives: yet, as Lamin Sanneh has argued in his theory of vernacularisation, the mother tongues in the translation of the Bible paradoxically consigned primacy to black African originality and agency and continue to undermine the arguments that seek to present Western cultural dispensation as superior. Sanneh (2001) says:

Accordingly, in the language projects of modern missions, Europe confronted the native character of non-Western races in its irreducible profundity, in its core self-understanding, rather than as space to be filled with European speech forms and habits only. (p. 17)

The reality of the desire to dismantle the cultural dispensation of black Africans exists up to this very day. Although this desire by the West was initially fraught with physical, violent terror by dismembering and excluding black Africans from the communion of the Homo sapiens, today, we argue, this desire is more subtle and sophisticated, as Ngugi wa Thiong'o has indicated above.

The point that Ninian Koshny (2006) makes is important for our consideration:

The shift in terminology from 'dominance' to 'hegemony' to 'empire' is significant, above all, because it highlights the classic concept of direct political control by an imperial centre. It is a question of indefinite dominance. The rhetoric, concept, strategy and policy of the empire camp are not new. The difference is that they are now in power. (p. 336)

Ninian Koshny is discussing 'empire', a term used in the Accra Confession, to define the character of the 21st century as a convergence of military power, politics, economics and culture.

With these insights, he elaborates on the discourse of the global empire, particularly its distinct features, and in relation to the spread of military power of the United States of America. The relevance of this quotation to our conversation is manifold. Obviously, one should concur with Koshny about the character of the 21st century, and there is no need to spend time on this matter as it is widely discussed in theological circles today. The poignancy of the sentiments above is nonetheless accentuated in the distinction we must make between the concepts of dominance, hegemony and empire. This is the point that is envisaged in this conversation. The brutal force of domination that was used to dismantle the black African dispensation shifted to hegemony which masquerades the 
initial bloodied and genocidal era of disruption to a more sophisticated dispensation in which a combination of all these strategies - mainly to maintain economic hegemony and, in fact, the control of the whole of life by empire - must be maintained. ${ }^{4}$ The desire to dismantle, or even to destroy, the black African cultural dispensation is a problem we should not overlook but keep as a pervasive methodological question in the quest for a spirituality of liberation which is rooted in the praxis of the AICs. This matter is discussed further when we look at the civilisation of the current order of the world and African religiosity. African religiosity is therefore a site of the spirituality of liberation in the context of a death dealing culture of the empire in the 21st century.

What we need to remember at this point is that the onslaught against the indigenous dispensation of the black African people entails the subversion of the 'native' as Sanneh argued. In other words, where it cannot be destroyed and dismantled it must be subverted. There are many examples that could be given about this discourse of subversion in South Africa. ${ }^{5}$ Arguably, the absence of the black African consciousness as a driving force for the transformation of our society after the demise of apartheid is one example. This point should not be misconstrued to imply that black African consciousness should be a replacement of the dominant and the erroneous status of the superiority of Western culture. Not at all! In the least, a commitment to the equality of all cultures could be the best thing to strive for.

The co-opting of black African cultural symbols in a number of spaces and places in South Africa today is an example of a continuum of subversive strategies that were used at the very first encounters between the West and Africa. Some churches ${ }^{6}$ for example use black African concepts or terminologies in their formal discourses. University faculties ${ }^{7}$ use black African concepts or terminologies too in the same manner as the political parties ${ }^{8}$ and government

4.Whilst South Africa attained its political liberation 20 years ago, its economic policies have been trapped in the dictates of the Washington Consensus, and policies have been trapped in the dictates of the Washington Consensus, and
poverty, inequality of unemployment have worsened since the demise of apartheid. The South African economic structure of apartheid has not changed and most importantly, the government led by the African National Congress does not own or even control the economy of this country. Whilst there seems to be no violent confrontation between the oppressed and the beneficiaries of the oppressive regime of the past, it cannot be disputed that the hegemony of neoliberal economics generally benefits the beneficiaries of apartheid.

5.First there is an important article that was written by Tinyiko Maluleke and Sarojin Nadar (2004) which we interpret as a discussion of the intellectual subversion of black African symbols. One equally potent work that sharply raises this point is Ivan Petrella's (2004).

6.The Uniting Presbyterian Church in Southern Africa for example uses the word taken from Chichewa in Zambia, insaka, to designate group work discussion of its assembly's decision making processes. What is interesting is how out-sided this concept has become in the proceedings of the Council of the General Assembly. concept has become in the proceedings of the Council of the General Assembly.
Insaka group meetings take place when the assembly breaks into groups, often even Insaka group meetings take place when the assembly breaks into groups, often even
outside the main venue of the assembly itself, barring logistics! At the centre of
the assembly discourse there is very little value of the black African palaver that the assembly discourse there is very little value of the black African palaver that
is integrated, worse in the denomination itself as the theological values that are assumed as core to the denomination are Western and white.

7.As a member of the Faculty of Theology in Pretoria, the use of the concept lekgotla is equally fascinating. It is a Sesotho name for an equivalent of res publica. This is how deeply the word should be understood: sharing of power, re-making of the community, dignity of the participants and so forth. Arguably, barring what some community, dignity of the participants and so forth. Arguably, barring what some might view, dis ane meetings and in its African import, let alone the epistemological implications of its use.

8.The African National Congress has used the concept of imvuselelo for the revival of its branches. This is even more intriguing as this concept is quintessentially liturgical and thus spiritual in its black African roots. institutions do. When the underlying values of these symbols are not negotiated into the dominating values of the West, they simply remain a ploy. Incidentally, the satisfaction that often becomes apparent on the part of those who perceive the inclusion of black African symbols either as concepts or terminologies in what is 'mainstream' discourse has become a feature in post 1994 South Africa.

Inclusion might not be an easy thing, we could concede, but as a form of strategy to subvert the cultural dispensation of the black African people it could be preferrable to the liberative content of this culture, or at least its equality amongst the cultures of the world. Without any liberation, inclusion could be deadly as it might simply imply assimilation and ultimately the death of consciousness. At its pioneering stages, the black theology of liberation had this to say:

Any advice from whites to blacks on how to deal with white oppression is automatically under suspicion as a clever advice to further enslavement. Furthermore, it is white intellectual arrogance which assumes that it has a monopoly on intelligence and moral judgement. (Cone 1989:20)

The discourse of inclusion does not only manifest itself in the vexing cosmetic use of black African symbols, but also often assumes in subtle ways that the selection of some of these symbols for inclusion should affirm the intelligence and moral judgement of the West. Cornel West (1979) is even clearer with regard to inclusion:

Liberation would consist of including Black people within the mainstream of liberal capitalist America. If this is the social vision of Black theologians, they should drop the meretricious and flamboyant term 'liberation' and adopt the more accurate and sober word 'inclusion'. (p. 556)

The implication of the sentiments above is vivid. There is a substantive difference between 'inclusion' and 'liberation.' Black theology of liberation responds to the subversion of the black African cultural dispensation by rejecting inclusion in favour of liberation which critiques the dynamics of the internal logic of superiority - the assumed monopoly and intelligence of Western forms of knowledge - from which black Africans must be liberated. Stated otherwise, Black Consciousness requires one to grasp the internal logic of Western superiority and debunk it. Then rise above the falsely assumed inferiority of blacks: hence the affirmation of blackness and, ipso facto, the equality of intelligent and moral forms of knowledge that are originally black African with any other forms of knowledge. This is the aspect we need to punctuate in our overview of black African spirituality and religiosity. This discussion must take place in the context of a continuous desire to obliterate aspects of this cultural dispensation and the strategies assumed to subvert, if not to dismantle and destroy, the totality of the black African dispensation. As an alternative to the authoritative salvationist dispensation of Western religiosity, black theology of liberation identifies the death of consciousness as its starting point. This struggle against death is enacted in the praxis of the AICs. 
As the site of the spirituality for liberation, African religiosity as expressed by AICs, mokhuku is not merely a quest for the inclusion of the African moral and ethical dispensation in the Western salvationist hegemonic forms of religiosity, but a well of liberating resources for life and consciousness on its own, and against extinction.

Indeed, by the close of the 20th century, the project of indigenisation, epitomised in the notion of inculturation, had produced impeccable proponents such Lamin Sanneh and Bediako Kwame. Tinyiko Maluleke described the work of these two scholars as translation theologies. He says:

Elsewhere I have linked these theologies to the names of Lamin Sanneh and Kwame Bediako. This, however, must be taken to mean that Sanneh and Bediako present us with exactly the same agenda. Both of them are important, innovative voices whose thinking bears significant implications for African theology as the twentieth century draws to a close. (Maluleke 1997:19)

The quotation taken from Sanneh: '[T]he logic of the translatability of the Christian message or gospel into African vernacular languages' (Maluleke 1997:19), the translation of Christianity into the mother tongue and thus the indigenous cultural dispensation remains an anticipated subversive site of the struggle against the clamour of Western superiority in the interpretation of this faith. Indeed, vernacularisation and translatability had become important variants of the inculturation methodology by the turn of the 20th century. In South Africa, Desmond Tutu had already postulated that the Bible that was used to take the land from black Africans had to be used to claim the very land back. Enculturation thus entailed translation and the struggle to claim back the space - the land - that was stolen from black people. In our own description of the developments in the contestation between the West and Africa, black Africans had learned how to 'colonise' for their own liberation the same instruments Christianity in particular - misused by the colonisers to subjugate them. Valentin Dedji (2003) spells out the historical development of methodologies and paradigms of African Christian theology. What became enculturation, liberation and reconstruction paradigms share a characteristic that Dedji (2003) describes in the following manner:

The task of the theologian, like the philosopher, is not just to interpret reality but, as Marx reminds us with his theses of Feuerbach, to change it. 'Africanization,' 'liberation,' and 'reconstruction' then can be described as hermeneutic procedures that seek both understanding of African cultural-political reality and the interpretation of this reality in the light of the gospel of Jesus, so as to bring about social and political transformation. (p. 262)

Clearly, methodology is important for anyone who is alert to schemes that seek to dismantle and subvert the cultural heritage of a black African person. Ultimately, the hermeneutical choice one makes must provide guidance for a commitment to socio-political and economic transformation. At the core of the methodological stages that have evolved in African theology is the notion of 'anthropological pauperisation' which, as stated in the Ecumenical Association of Third Theologians' (EATWO) assembly, is expressed in this manner:
The social development of Africa represents a fundamental aspect of the anthropological pauperisation of the African person. If we define pauperisation as the fact of becoming or making poor, namely being deprived of all that we have acquired, all that we are and all that we do, we shall recognise that African is subjugated to structures which result in complete pauperisation: political, economic, and social. When it is not a matter of being deprived of all that we own, but rather of all that we are-our human identity, our social roots, our history, our culture, our dignity, our rights, our hopes, and our plansthen the pauperisation becomes anthropological. It then affects religious and cultural life at its very roots. (Dedji 2003:258)

This statement was made in 1986 and no one can deny that since 1989 and 1994 in South Africa, important changes have taken place. One such change is the democratic wave that engulfed not only our continent, but also other parts of the globe. Yet anthropological pauperisation is still a relevant methodological category that should inform theological discourse on our continent. The discussion about the rough sketch of the methodological development of African Christianity is that enculturation, liberation and reconstruction - as hermeneutic procedures that have sought to understand the cultural-political reality of black African people and thus African religiosity - is, paradoxically, also equally about a tragic spirituality of African religiosity. At root level, the discussion of African religiosity as indicated by this overview of the development of this trajectory is tragic.

It is an overview of a spirituality of woundedness: a site of a spirituality that harnesses life in the resources of African values and a refusal of the death of consciousness.

\section{African spirituality: A resource for an alternative civilisation}

As we have already argued, African religiosity is often more pragmatic and this-worldly than it is an esoteric phenomenon, as is mostly found in some Western forms of Christian spirituality (Anderson 2000:17). Spirituality is the soul of culture and embraces one's whole religious experience - beliefs, convictions, patterns of thought and emotions about the ultimate understanding of the transcendent. It is for this reason that we should avoid any dualities between spirituality and consciousness when we think about the black African imagery and religiosity. One is the other side of the other. According to Jon Sobrino (1988), there is no spirituality without life, so it is important to avoid making these artificial dualities that are common in Western thought. What this means for our conversation is ultimately important.

Firstly, any pondering of spirituality without considering the lives of the poor remains pie in the sky. Indeed, black Africans believe that the whole of life is infiltrated by spirituality. This means that the African comprehensive view of life could be regarded as the praxis of lex orandi, lex credenti. In this manner, African life as a whole is prayer and believing. It is public theology, so there are many assets of spirituality that easily derive from this understanding. In line with our understanding of black theology of liberation, the struggles of the poor are a fountain of spirituality. According to Terry Eagleton (2009): 
The only authentic image of this violently loving God is a tortured and executed political criminal, who dies in an act of solidarity with what the Bible calls the anawim, meaning the destitute and dispossessed. (p. 23)

In this regard the poor are an image of the future in their very poverty. African religiosity offers a deeper meaning of the mystery of the preferential option for the poor.

Secondly, against the challenges of life and indeed the threats of death that the 21st century displays, African religiosity is an important asset for life-giving spirituality amidst the secularised eschatology of the global market. In this context, the spirituality resonant with African religiosity offers a basis from which Christ's Gospel could be 'saved' from the claws of empire. The point in this section should be clear. Much as the AICs and therefore African religiosity offers resources for the spirituality of liberation for black Africans, the Gospel itself requires to be salvaged from the ascendancy of a particular form of civilisation that has been obstinately portrayed as the only truthful mediation of life in the 21st century.

\section{Reformed faith and African religiosity}

It might be good for us to briefly map what the spirituality of liberation implies for this heritage. Heleen Zorgdrager (2011) is correct in referring to the variety of contextual expressions of this heritage. She makes the following point:

The Reformed tradition has always felt more comfortable with theologies that start from diversity than with those that find their point of departure in unity. The preferred model is 'unity in diversity' and not 'diversity in unity' in the polarity between the contextual and the universal the balance swings to the contextual, the particular. However, this caveat must be borne in mind: Reformed churches have proven to be champions of creedal doctrines and confessional documents, which they have tended to see as expressing transhistorical and thus universal truth (p. 161)

It is important to remember that the sentiments above come from a time when the two global former ecumenical bodies of the Reformed faith came into union in 2010 in Grand Rapids. Heleen Zorgdrager is essentially reflecting on some of the recommendations that were proposed in the inaugural assembly of the World Communion of Reformed Churches. She aptly discusses what she designates 'topics of debate and discord,' and identifies women's ordination, homosexuality, and the theology of justice as some of these topics (Zorgdrager 2011:161-163).

Interestingly, she does not only identify these topics of debate and discord, but actually makes her biases clear at the same time. She sees culture as one dominant element in the areas of women's ordination and homosexuality and, indeed, even in the debates and discords around the Accra Confession. In other words, she seems to imply that the interpretative exercise of the Accra Confession is mostly cultural and less theological: hence it must be repudiated for its attempt at universalising what should actually be the contextual 'cultural' concerns it raises. Engaging Heleen Zorgdrager is a subject for another article. The importance of her article arises from what the questions are, and indeed, what she asks about Africa is even more fascinating: 'I would be interested to hear about possible models from Asian, African or Latin American background. Are there more alternatives of negotiating the local and the global in theology?' (Zorgdrager 2011:168).

It is not just an accident that amongst these questions of debate and discord there are silent ones too. The responsibility of the Reformed faith itself and its culpability in the destruction of the African dispensation and the subversion of its internal logic must be constantly put on agenda. As Anderson (2000:17) aptly argues, divine revelation must be sought in the experience of Africa in relation to the Reformed heritage as part of an expansionist, authoritative salvationist religiosity of the West. One of the topics the Reformed faith cannot avoid is what Rothney Tshaka (2011) has expressed as 'notions of Africanness.' As a confessional form of faith, Tshaka poses an important question about the embodiment of confessional faith in the Reformed tradition. Therefore, in these questions of debate and discord in the new Communion, there are deeper questions that call for attention, one of which is African religiosity. It might be important to make a remark about the problem of particularity and universality specifically in relation to black theology of liberation. Theo Witvlei (1987) said:

We have seen that in its initial phase black theology tended
more to be a survival theology than a real theology of liberation.
Granted, the term 'survival' here has absolutely no pejorative
connotations. Why should survival, in whatever form, not come
first for a people who has had to undergo so many traumas? Who
has the right to pass a negative judgment here? However, it is an
unmistakable fact that the black struggle for survival has never
been without a wider vision, one extending to total liberation
in a world without tears. From the beginning this inclusive
dimension was also present in black theology. Especially thanks to
experiences in peripheral ecumenism this dimension has become
more visible. Black theology now moves in the field of tension
between particularity and universality, kairos and context. (p. 243) The question of particularity and universality about black theology of liberation was posed by Witvlei some 27 years ago. Notions such as 'survival theology,' 'world without tears,' 'peripheral ecumenism' and 'kairos and context' are fascinating as they bring Witvlei closer to Zorgdrager's reflections in 2011. Tshaka (2011) also discusses the question of particularity in relation to confession and embodiment. We bring to the fore, as we conclude this conversation, the question of paradigm, particularly what Edgar Engelbrecht (1987) argued:

The understanding of a rival system which is based on a radically different paradigm or the defence of the own system against a system based on a radically different paradigm, often involves illegitimate prejudices. The illegitimacy of these prejudices becomes clear when the criterion of scope is applied to them. A reductionist scope is often indication of illegitimate prejudice. (p. 10)

What does the relationship between Reformed faith and African religiosity signify? Does it imply the 'inclusion' of the black African dispensation in its central tenets, or does it 
signify the liberation of African religiosity within its tenets? Put differently, one could pose the question as to whether African religiosity is an embodiment of the Reformed faith liberated in South Africa, or not? No amount of prejudice will disqualify African religiosity as an expression of the struggle for life, sanity and liberation against the perpetual desire to subvert, drain and destroy the historical memory of black Africans. If the imago Dei - as Dickson (1991) argues - is the basis of equality of all cultures, its inclusion in the family of Christ, sola fide, is meaningful with African religiosity as its indispensable component, at least in South Africa.

\section{Conclusion}

We have presented an overview of African religiosity in this article and the sanity it continues to offer as a resource in spaces of lived insanity in South Africa, as well as a site of the spirituality for liberation. Cultural liberation, African history, agency, originality and consciousness are some of the resources that emerge strongly out of the fountains of African religiosity. In addition to its indispensable place in the agenda of the Reformed faith in the 21st century, African religiosity is, in the quest for alternative forms of civilisation, an important resource.

\section{Acknowledgements Competing interests}

The author declares that he has no financial or personal relationship(s) that may have inappropriately influenced him in writing this article.

\section{References}

Anderson, A., 2000, Zion and Pentecost: The spirituality and experience of Pentecostal and Zionist/Apostolic churches in South Africa, University of South Africa Press, Pretoria.

Cone, J, 1989, Black Theology and Black Power, Harper, San Francisco.
Chung, P. \& Duchrow, U., 2011, Liberating Lutheran theology: Freedom for justice in a global context, Fortress, Minneapolis.

Dedji, V., 2003, Reconstruction and renewal in African Christian theology, Acton, Nairobi.

De Gruchy, J., 1991, Liberating reformed theology: A South African contribution to an ecumenical debate, Eerdmans, Grand Rapids.

Dickson, K.A., 1991, Uncompleted mission: Christianity and exclusivism, Orbis, Maryknoll.

Eagleton, T., 2009, Reason, faith and revolution: Reflections on the God debate, Yale University Press, London.

Engelbrecht, E., 1987, The pattern of religion in the Black Theology of of James Cone, s.n., Pretoria.

Gibson, N.C., 2011, Fanonian practices in South Africa, University of KwaZulu Press, Scottsville.

Koshny, N., 2006, 'The global empire: An overview', Reformed World 56(4), 335-354.

Maluleke, T.S., 1997, 'Half a century of African Christian theologies: Elements of the emerging agenda for the twenty-first century,' Journal of Theology for Southern Africa $99,4-23$

Maluleke, T. \& Nadar, S., 2004, 'Alien fraudsters in the white academy: Agency in gendered colour,' Journal of Theology for Southern Africa 120, 5-17.

Ngugi wa Thiong'o, 2009, 'Recovering our memory: South Africa in black imagination,' in Steve Biko Foundation, The Steve Biko Memorial Lectures 2000-2008, pp. 51-72, Pan Macmillan, Johannesburg.

Petrella, I., 2004, The future of liberation theology: An argument and manifesto, Ashgate Publishing Limited, Hampshire.

Sanneh, L., 2001, 'The African transformation of Christianity: Comparative reflections on ethnicity and religious mobilization in Africa', in D. Hopkins, L.A. Lorentzen, E. Mendieta \& D. Bastone (eds.), Religions/Globalizations: Theories and cases, pp. 1-79, Duke University Press, London. http://dx.doi. Theories and cases, pp. 1-79, Duk
org/10.1215/9780822380405-007

Sanneh, L., 1989, Translating the message: The missionary impact on culture, Orbis, Maryknoll.

Sobrino, J, 1988, Spirituality of liberation, SCM, London.

Stackhouse, M., 2004, 'Public theology and political economy in a globalizing era,' in W.F. Storrar. \& R. Morton (eds.), Public theology for the 21st century, pp.179-194, T\&T Clark, London, New York.

Tshaka, R., 2011, 'Confessional Theology as belligerently public theology: How confessional theology relates to the notions of Africanness and Reformedness', in L. Hansen, N. Koopman \& R. Vosloo (eds.), Living theology: Essays presented to Dirk Smit on his sixtieth birthday, pp. 292-304, SunMedia, Stellenbosch.

Vellem, V.S., 2012, 'The Opiate of neoliberal globalization and the dawn of democracy in South Africa', Theologia Viatorum 36(1), 76-93.

Vellem, V.S., 2013, 'Reformed tradition as public theology', HTS Teologiese Studies/ Theological Studies 69(1), Art. \#1371, 5 pages. http://dx.doi.org/10.4102/hts. v69i1.1371

West, C., 1979, 'Black theology and Marxist yhought', G.S. Wilmore \& H.J. Cone (eds.), Black theology: A documentary history, 1966-1979, pp. 552-567, Orbis, Maryknoll.

Witvlei, T., 1987, The hermeneutical challenge of Black theology as a theology of liberation, SCM, London.

Zorgdrager, H., 2011, 'In search of a shared theology: Reformed theology between the contextual and the universal', Reformed World 61(3), 159-170. 